\title{
Special Issue: Carol Smart's Feminism and the Power of Law
}

\author{
Rosemary Auchmuty • Karin Van Marle
}

Published online: 29 July 2012

(C) Springer Science+Business Media B.V. 2012

\section{Introduction}

This special issue derives from a workshop held in April 2010 in Marrakech by the Working Group on Gender and Law of the Research Committee on Sociology and Law. The workshop took as its theme 'Law and the power of feminism', a title derived from Carol Smart's book Feminism and the Power of Law (1989) which had just celebrated the twentieth anniversary of its publication. Contributors to the workshop (who came from Australia, Canada, South Africa, the United Kingdom and the United States) were invited to present papers on their own research interests that engaged with the arguments of Feminism and the Power of Law. Although the book was our starting-point, the papers were not intended to offer a direct critique of the book or Smart's work generally. Rather, the workshop presented an opportunity to demonstrate (rather than to assess) the continuing significance and relevance of Smart's ideas across a range of subject areas and jurisdictions - to show, indeed, what an inspiration she has been to us all.

Carol Smart is a sociologist, whose early work (Women, Crime and Criminology, 1976, and Women, Sexuality and Social Control, 1978, with Barry Smart) made a huge impact on the male-dominated disciplines of criminology and socio-legal studies and helped to establish a legal presence in the developing field of women's studies. In The Ties That Bind (1984) she contributed a powerful legal perspective to the second-wave feminist critique of marriage while simultaneously applying insights from the women's movement to legal scholarship. This exploration of the relationship between

\footnotetext{
R. Auchmuty ( $($ )

School of Law, University of Reading, Foxhill House, Whiteknights Road, Reading, RG6 7BA, UK e-mail: r.auchmuty@ reading.ac.uk

K. Van Marle

Department of Jurisprudence, Faculty of Law, University of Pretoria, Private bag X20, Pretoria, Hatfield 0028, South Africa

e-mail: Karin.VanMarle@up.ac.za
} 
feminism and law, and examination of law's role in the achievement of women's liberation, set the terms for the new field of feminist legal studies.

Feminism and the Power of Law, which followed in 1989, took as its point of departure the idea that "in accepting law's terms in order to challenge law, feminism always concedes too much" (Smart 1989, 5). In this book Smart sought to "de-centre" law, to think of "non-legal strategies", and to "discourage a resort to law as if it holds the key to unlock women's oppression" (5). Significantly, she included in her 'resort to law' not merely policy proposals, but also scholarship. The book was instantly influential, becoming perhaps the best-known and most-cited book in British feminist legal studies.

In the many books, articles, chapters and reports that have followed, Carol Smart has returned time and time again to the relationship between women and law. In her work on how people conduct their personal lives, in couple and parent-child relationships as well as with wider kin and friendship networks, she remains fascinated by "how law influences our personal lives" and "how and why we often turn to law for solutions to personal dilemmas" (Smart 2012). These days she is not as critical of law as she once was, perceiving its positive capacity to adapt to social change and to offer recognition and affirmation alongside unwanted regulation and control. Unsurprisingly, some of the contributors to the Marrakech workshop chose to engage with aspects of her later work as well as with Feminism and the Power of Law, taking issue with some of her arguments while endorsing others.

From that 2010 Marrakech workshop the editors of this special issue of Feminist Legal Studies selected five papers for publication. Each draws on an argument from Feminism and the Power of Law to consider retrospectively the impact of Carol Smart's work on feminist scholarship, feminist lawyering and feminist activism in their own field and jurisdiction. Carol kindly agreed to read all the papers; her generous response is taken up as an afterword.

Against the background of Smart's call for feminists to use non-legal strategies rather than looking to law to bring about women's liberation, with reference to the example of marriage in England and Wales, Rosemary Auchmuty contends that Smart was right. Statistics and contemporary commentary show how marriage, once the ultimate and only acceptable status for women, has declined in social significance to such an extent that today it is a mere lifestyle choice. For Auchmuty, the primary catalyst for change was the feminist critique that called for the abandonment (rather than the reform) of the institution and made the unmarried state possible for women. Echoing Smart's argument she argues that we should continue to be wary of looking to law to solve women's problems.

Bev Baines draws on Carol Smart's argument that "law must also be tackled at the conceptual level if feminist discourses are to take a firmer root" (Smart 1989, 5) and engages in this vein with the Women's Legal Education and Action Fund (LEAF) in Canada who 'tackled' the concept of comparison in the age equality case of Withler v Canada, 2008 BCCA 539. Rejecting 'similarly situated' (or “groups") comparison as inconsistent with substantive equality, LEAF advocated a "contextual' approach to import gender into the Withler frame. Baines argues that LEAF could have named the patriarchal state as the male comparator in Withler, thereby aligning their contextual approach with 'grounds' comparison and offering 
substantive equality a 'firmer root'. However, she asks at the end of her paper if LEAF would have had greater success if it followed non-legal strategies.

Helen Carr and Caroline Hunter take as starting point the shift from Smart's 1989 position that problematised law as a masculinist knowledge disqualifying other forms of knowledge, particularly feminism, to her position 21 years later that characterised the relationship between law and feminism quite differently. In this account, law responds to feminism and outcomes are progressive. In a study on the Albert Kennedy Trust (AKT), they test Smart's suggestion that rather to continue to focus on law's disciplinary and normalising role it could be more productive to conceptualise contemporary family law as a creative kinning practice. AKT was established in 1989 in the wake of gay and lesbian resistance to Clause 28 of the Local Government Bill, which prohibited the 'promotion' of homosexuality, to provide homes with gay and lesbian adults for homeless gay and lesbian teenagers. They focus on AKT's shift in its description of the adults' relationship with the teenagers in their care from 'brothers and sisters' to 'carers' as it moved from a marginal force to mainstream partner/ provider. In this context they explore the complexity of law's responsiveness to feminism's dynamism, its contingent recognition of kinning practices and its continuing disciplinary role. Law's acceptance of feminism's offer is not only found in the liberalisation of the family but also in the reconfiguration of the state.

Heather Douglas takes up Smart's suggestion to examine the way the law works in practice. She explores the context of current criminal prosecutions of domestic violence offences in Queensland, Australia. Focussing on legal method she argues that it is applied outside the higher courts or 'judge-oriented' practice and that the obstacles inherent to legal method can be identified in the practices of police, lower court staff, magistrates and lawyers. She suggests that it may be difficult to deconstruct legal method, even by focussing on law in practice, and as a result it may be difficult to successfully challenge law's truth claims in this way. The analysis of criminal prosecutions of domestic violence offences reported here supports Smart's earlier findings that women and children who seek redress through the criminal justice process find the process at best ambivalent and at worst, destructive. However, she also shows how, in the Queensland context, women sometimes find their way to feminism and personal empowerment by going to law.

Rosemary Hunter analyses two feminist judgment-writing projects, the Women's Court of Canada (WCC), and the Feminist Judgments Project (FJP) in England, in light of Carol Smart's feminist critique of law and legal reform and her proposed feminist strategies in Feminism and the Power of Law (1989). She considers the extent to which feminist judgment-writing projects either reinforce Smart's conclusions or challenge them. In her view, while some of Smart's contentions have proved unsustainable, others remain salient and have both inspired and hold important cautions for feminist judgment-writing projects.

Karin van Marle engages with Smart's main claims by way of a number of other thinkers. Following Marianne Constable's description of contemporary American legal thought as socio-legal, she asks to what extent contemporary legal feminism has adopted sociological method, resulting in a similar absence of justice that concerns Constable. Smart's caution against the development of a feminist jurisprudence is critically analysed with the benefit of hindsight. Drawing on 
Deleuze and Guattari, Foucault and Goodrich, van Marle tentatively considers the becoming of a feminist jurisprudence as a minor jurisprudence.

As this summary shows, the aim of this special issue is not to force specific themes; the initial event was loosely framed around Smart's 1989 work and these papers resulted from there. This explains the diversity of topics and angles chosen by the authors, while taking the main insights from the book as starting point. Questions posed included the extent to which Smart's basic point of departure has proved to be true, given feminist experience since the publication of her book; the extent to which her call for a decentring of law was taken up in or has had an impact on feminist legal scholarship; the extent to which her ideas have influenced the work of courts and initiatives for legal reform; and the extent to which her work has been taken up in feminist activism and social action in the range of jurisdictions represented in the Working Group. If any conclusion can be drawn, it is that Carol Smart's ideas (even those which she later modified) have been pivotal in the development of feminist legal activism as well as feminist legal theory. Central to Feminism and the Power of Law was the relation between knowledge, law and feminism. Baines, Hunter and Van Marle respond in different ways, ranging from a consideration of a litigation project through a reflection on a project on feminist judgments to an engagement with the notion of a feminist jurisprudence, to Smart's claim that feminism too often concedes to the knowledge and method of law, rather than to rely on feminist knowledge and method drawing on experience. Auchmuty, commenting on social change by looking at the demise of marriage, argues that Smart was right in insisting on the use of non-legal strategies. The contributions by Carr and Hunter and Douglas touch on the relation between NGOs, feminism and the state. The papers by Hunter and Van Marle raise questions on the possibilities of being and becoming and the role of feminism to push for alternatives.

It is hard to imagine now, when feminist legal scholarship is a respectable and established (though still often marginal) field, how completely it was once ignored or dismissed as the lunatic outpourings of disgruntled women who failed to respect the fundamental objectivity of law. This special issue of a journal dedicated to its pursuit celebrates Carol Smart's role in making feminist legal studies-not to speak of sociolegal studies generally - accepted and, indeed, influential. Coming as she did from outside the discipline of law, she immediately challenged law's closed and selfreferential nature; and, in spite of the fears expressed in Feminism and the Power of Law that law would remain impervious to non-legal critique, developments not only in the academy but in the courts have happily proved her to be wrong. Smart's later conviction that law can sometimes be positively useful to feminists provides encouragement to those who continue to strive not only to deconstruct but to reconstruct laws and legal processes to serve the goals of justice and equality.

\section{References}

Smart, Carol. 1976. Women, crime and criminology: A feminist critique. London: Routledge and Kegan Paul. 
Smart, Carol. 1984. The ties that bind: Law, marriage and the reproduction of patriarchal relations. London: Routledge and Kegan Paul.

Smart, Carol. 1989. Feminism and the power of law. London: Routledge.

Smart, Carol. 2012. 'Professor Carol Smart'. Morgan Centre for the Study of Relationships and Personal Life, University of Manchester. www.socialsciences.manchester.ac.uk/morgancentre/people/staff/ index.html, Accessed 20/06/2012.

Smart, Carol, and Barry Smart. 1978. Women, sexuality and social control. London: Routledge. 